\title{
Curriculum Implementation and Feedback Mechanism at Secondary School Level in Punjab Pakistan
}

\author{
Zahid Hussain \\ PhD Scholar, Department of Education, Islamia University of Bahawalpur, Pakistan \\ Prof. Dr. Aslam Adeeb \\ Department of Education, Islamia University of Bahawalpur, Pakistan \\ Hassan Danial Aslam \\ Lecturer, Department of Management Sciences, Islamia University of Bahawalpur, Pakistan \\ Doi:10.5296/ijld.v1i2.6645 URL: http://dx.doi.org/10.5296/ijld.v1i2.6645
}

\begin{abstract}
The article is planned to investigate curriculum implementation and feedback mechanism at secondary school level in Punjab Pakistan. Data was collected from randomly selected 23 curriculum experts from Ministry of Education, curriculum wing Punjab and Punjab Textbook Board. Data was statistically treated using percentage and mea score. Finally keeping in view the major findings of data, conclusions and recommendations were formulated. The study conclude proper implementation and monitoring mechanism need to be reconsider in curriculum development process.
\end{abstract}

Keywords: Curriculum implementation, Curriculum Monitoring, Feedback

\section{Introduction}

Curriculum development is planning to organize a programme to manage available resources like space, time, material, equipment and individuals in a logical way to recast the educational process as a whole. The next step is curriculum implementation which involves application of resources and training for those in need of skills. In the case of science curriculum the implementation function involves, helping teachers to use curriculum effectively by holding workshops and orientation courses, improving the provision of laboratories and equipment, introducing more appropriate form of examination for students who had completed the course.

At this stage teacher deliver the curriculum in actual classroom setting. Difficulties in delivering curriculum, gaps in teaching and learning are identified and are used for curriculum improvement in future. Curriculum implementation refers restructuring of education program that include adjusting personal habits, course emphases, ways of behaving, existing schedules and learning spaces. All these modifications depend partially on the excellence of the initial planning with which steps of curriculum development have been carried out. For successful curriculum implementation, curriculum leaders must consider in-service training offered to the teachers, availability of competent teachers, efforts for training of pre-service teachers for implementation of new curriculum. They must take decisions about correct orientation of teacher-learner interaction, new learning material given to the students and resource material supplied to the teachers.

*PhD Scholar, Department of Education, The Islamia University of Bahawalpur (Pakistan) 
** Lecturer, Department of Management Sciences, The Islamia University of Bahawalpur

It also includes take decisions about new curriculum assessment procedures and detail procedure to deal with the problems encountered in curriculum implementation. Finally they have to take decisions for the formulation of check list to monitor the newly implemented curriculum and procedure for successful monitoring and feedback. Other important aspects that should be considered in this regard are student background and understanding, teacher attitude and proficiency, the school environment, resources available and external restrictions.

Curriculum development process is not static rather it is continuous and cyclic and undergoes continual process of modification in the light of feedback obtained through constant monitoring of existing curriculum. It does not lead to a finished final product and demand for continues improvement in the light of continuously changing needs of society. It means that continuous monitoring and evaluation should be implanted as vital parts in curriculum development process. Unfortunately, this aspect of curriculum development was seen weak in Pakistan. Monitoring and evaluation of curriculum mechanism either not exist or do not function properly in Pakistan. Due to this reason, proper feedback was not available for the improvement of existing curriculum or to provide robust foundation for new curriculum reform. It is an unavoidable fact that monitoring is necessary to improve curriculum, textual material, teachers' delivery and policy formulation.

It is thought that our curriculum development organizations lack such a system that ensures continuity and alignment in curriculum development, as a result the impact on the content selection, textbook formulation, the quality of teaching and assessment procedures remained limited. It is also whispered that there is a gap between curriculum developers and teachers; moreover teacher's role was neglected in past, who can act as a catalyst in generating interactions between school, students and teaching materials.

The present study is an effort to identify weaknesses in curriculum implementation and curriculum monitoring procedures so that the decisions about selection of objectives, contents, teaching methodologies/approaches and assessment procedures can be taken more deliberately in the light of proper feedback.

\section{Objectives}

Major objectives of this study were to:

1- Investigate the curriculum implementation mechanism at secondary school level.

2- examine curriculum monitoring mechanism at secondary school level

3- Suggest some recommendations for effective mechanism of curriculum implementation and monitoring.

\section{Procedure of Research}

Questionnaire on four point scale was used as a tool to collect the data from respondents. The population of the research was curriculum experts working in Ministry of Education, curriculum wing Punjab and Punjab Textbook Board. Data was collected from randomly selected curriculum experts. The responses were analyzed by using $\operatorname{SPSS}^{\mathrm{TM}} 13$. The data was tabulated and passed through statistical analysis using percentage and mean score. Finally keeping in view the major findings, conclusions and recommendations were formulated.

\section{Literature Review}

A curriculum without content is no curriculum; a curriculum without experiences cannot be delivered or encountered by students, a curriculum without planed environment cannot be implemented by teacher". Curriculum implementation is a sum of processes associated with attempts by teachers to transform a printed programme of study in to classroom reality (Shami, 1993). Mostly curriculum implementation is considered as distinct stage although it is an 
essential part of curriculum development process. Successful curriculum implementation depends on those decisions taken during curriculum development process for its implementation. Arranging a staff workshop for curriculum implementation is not enough; implementation involves attempts to change individuals' knowledge, attitudes and actions; it involves interactions between curriculum planers, management, teachers, students and all stakeholders (Ornstein and Hunkins, 1993). Ajibola (2008) also emphasized that in-service teachers should be given further training to teach new / revised curriculum and for this purpose new experts have to be trained locally or abroad. Govt of Pakistan (2006) has acknowledged that the teacher training should be essential part of curriculum implementation and each textbook must have a teacher's guide and teachers must be given special training for proper implementation of new curriculum. Ravi (2000) has explained that teachers' guide plays an important role in implementation of science curriculum. It guides a teacher how deep a topic should be explored; why certain things are included in the curriculum and how they provide the basis for the something coming later. A teacher's guide includes experimental details and instructions for effective use of apparatus. "Govt. of Pakistan (2009) has accepted that curriculum experts have faced a number of problems in past at curriculum implementation level in Pakistan. These hurdles include, lack of whole sector view, lack of clarity in roles and responsibilities in fragmented authorities, weak planning and management, lack of policy coherence, lack of stakeholders' participation and parallel system of education. Govt of Pakistan has taken various steps at different levels in education policy (2009) to overcome these hurdles. Balim and Kucuk (2010) after analyzing Turkish and Portuguese science curricula concluded that similarities occur in the basic aims of science curricula of both countries; performance regarding to science achievements of students of both countries stay under the international average. The possible reason for this poor situation may be due to meager curricula implementation processes of both countries. They suggested that curriculum implementation process, learning environment and role of teacher need to be considered. Both countries need to focus their attention on teacher training and curriculum implementation process. Investigating the same phenomenon Usta, Ceng, Kasli, \& Ayas (2009) have indicated some problems faced by teachers in implementation of chemistry curriculum. These are insufficient time, density of the concepts, lack of enough activities and inclusion of some topics which are not suitable to do student center-activities. They recommended to, increase time duration for chemistry lesson, decrease concept density, in-service teacher training and provision of teacher guidebook consisting of alternate activities. Farooq (1985) put forth several recommendations for the implementation of curriculum. These are given below:

- Development and revision of the curriculum should be exhibited on continuous and ongoing basis rather than a one time or emergency activity.

- Curriculum development should occur at regional level with respect to the national level needs. Presently curriculum is developed at national level which should be decentralized to regional levels as well.

- Focus should be built on improving the effectiveness of skills for teaching rather than just locating the skills.

- Research oriented supervisors and subject specialists should be hired because they are equipped with the latest and up to date knowledge.

- Research centers should be developed at the regional levels that are aimed to the continuous improvement of the curriculum.

- Research centers should appoint leaders that are produced by the Institutes of Education and Research.

- Concepts understanding should be stressed rather than understanding the facts. 
- Behavioral terms should be used to define the Educational objectives.

A more comprehensive picture of curriculum development and implementation is presented by (Iqbal, 2011). According to him mostly the process of curriculum revision in Pakistan is carried out in haste without proper planning and grassroots evaluation of existing curriculum. Persons concerned with curriculum development mostly did not know the causes of failure of existing curricula or the reasons for change. They are not clear in their minds about the objectives of curriculum revision and usually ignore the needs of learner, the problems of teachers and the material required for the introduction of new curricula. Consequently, revised curriculum is not more than listing and reshuffling of various topics and experiments. Another problem is lack of participation and lack of communication among various stakeholders in curriculum development process. As members of curriculum committee usually have unique set of views, beliefs and some time personal loyalties, they do not understand each other's point of view and it becomes difficult to congregate at any common point in democratic setting. As a result, proposed changes and innovations are not seen or understood.

\begin{tabular}{|c|c|c|c|c|c|c|c|}
\hline \multicolumn{8}{|c|}{ Finding } \\
\hline S.No & $\begin{array}{l}\text { Statement } \\
\text { Do you think that at secondary } \\
\text { school level: }\end{array}$ & $\begin{array}{l}f \\
\%\end{array}$ & SDA & DA & $\mathbf{A}$ & $\mathbf{S A}$ & $\begin{array}{l}\text { Mean } \\
\text { Score }\end{array}$ \\
\hline 1 & $\begin{array}{l}\text { There is proper mechanism for } \\
\text { implementation of curriculum at } \\
\text { secondary level. }\end{array}$ & $\begin{array}{l}\mathrm{N} \\
\%\end{array}$ & $\begin{array}{l}1 \\
4.4\end{array}$ & $\begin{array}{l}3 \\
13.0\end{array}$ & $\begin{array}{l}17 \\
73.9\end{array}$ & $\begin{array}{l}2 \\
8.7\end{array}$ & 2.87 \\
\hline 2 & $\begin{array}{lrr}\text { Curriculum } & \text { provides } & \text { adequate } \\
\text { guidelines } & \text { for } & \text { its } \\
\text { implementation. } & & \\
\end{array}$ & $\begin{array}{l}\mathrm{N} \\
\%\end{array}$ & $\begin{array}{l}1 \\
4.4\end{array}$ & $\begin{array}{l}5 \\
21.7\end{array}$ & $\begin{array}{l}17 \\
73.9\end{array}$ & $\begin{array}{l}0 \\
-\end{array}$ & 2.70 \\
\hline 3 & $\begin{array}{l}\text { Instructions are made available } \\
\text { for curriculum implementation } \\
\text { to school heads. }\end{array}$ & $\begin{array}{l}\mathrm{N} \\
\%\end{array}$ & $\begin{array}{l}3 \\
13.0\end{array}$ & $\begin{array}{l}6 \\
26.1\end{array}$ & $\begin{array}{l}14 \\
60.9\end{array}$ & $\begin{array}{l}0 \\
-\end{array}$ & 2.48 \\
\hline 4 & $\begin{array}{l}\text { Guidelines clarify the pattern of } \\
\text { teacher-learner interaction in } \\
\text { science class. }\end{array}$ & $\begin{array}{l}\mathrm{N} \\
\%\end{array}$ & $\begin{array}{l}1 \\
4.4\end{array}$ & $\begin{array}{l}4 \\
17.4\end{array}$ & $\begin{array}{l}18 \\
78.3\end{array}$ & $\begin{array}{l}0 \\
-\end{array}$ & 2.74 \\
\hline 5 & $\begin{array}{l}\text { Teachers' training is ensured } \\
\text { before implementation of new } \\
\text { curriculum. }\end{array}$ & $\begin{array}{l}\mathrm{N} \\
\%\end{array}$ & $\begin{array}{l}3 \\
13.0\end{array}$ & $\begin{array}{l}15 \\
65.2\end{array}$ & $\begin{array}{l}5 \\
21.7\end{array}$ & $\begin{array}{l}0 \\
-\end{array}$ & 2.09 \\
\hline 6 & $\begin{array}{l}\text { Resource material is provided } \\
\text { for implementation of new } \\
\text { curriculum. }\end{array}$ & $\begin{array}{l}\mathrm{N} \\
\%\end{array}$ & $\begin{array}{l}2 \\
8.7\end{array}$ & $\begin{array}{l}11 \\
47.8\end{array}$ & $\begin{array}{l}9 \\
39.1\end{array}$ & $\begin{array}{l}1 \\
4.4\end{array}$ & 2.39 \\
\hline 7 & $\begin{array}{l}\text { Curriculum action plans include } \\
\text { target for student achievement. }\end{array}$ & $\begin{array}{l}\mathrm{N} \\
\%\end{array}$ & $\begin{array}{l}1 \\
4.4\end{array}$ & $\begin{array}{l}5 \\
21.7\end{array}$ & $\begin{array}{l}16 \\
69.6\end{array}$ & $\begin{array}{l}1 \\
4.4\end{array}$ & 2.74 \\
\hline 8 & $\begin{array}{l}\text { Impact of implementation of } \\
\text { curriculum is determined by } \\
\text { classroom practice. }\end{array}$ & $\begin{array}{l}\mathrm{N} \\
\%\end{array}$ & $\begin{array}{l}3 \\
13.0\end{array}$ & $\begin{array}{l}8 \\
34.8\end{array}$ & $\begin{array}{l}10 \\
43.5\end{array}$ & $\begin{array}{l}2 \\
8.7\end{array}$ & 2.48 \\
\hline 9 & $\begin{array}{l}\text { Impact of implementation of } \\
\text { curriculum is determined by } \\
\text { pupil achievement. }\end{array}$ & $\begin{array}{l}\mathrm{N} \\
\%\end{array}$ & $\begin{array}{ll}1 \\
4.4\end{array}$ & $\begin{array}{l}5 \\
21.7\end{array}$ & $\begin{array}{l}13 \\
56.5\end{array}$ & $\begin{array}{l}4 \\
17.4\end{array}$ & 2.87 \\
\hline 10 & $\begin{array}{l}\text { The self-evaluation process is } \\
\text { embedded in the curriculum } \\
\text { implementation process. }\end{array}$ & $\begin{array}{l}\mathrm{N} \\
\%\end{array}$ & $\begin{array}{l}2 \\
8.7\end{array}$ & $\begin{array}{l}7 \\
30.4\end{array}$ & $\begin{array}{l}13 \\
56.5\end{array}$ & $\begin{array}{l}1 \\
4.4\end{array}$ & 2.57 \\
\hline
\end{tabular}




\section{MInstitute Macrink $_{\text {ins }}^{\text {Mank }}$}

\begin{tabular}{|c|c|c|c|c|c|c|c|}
\hline 11 & $\begin{array}{l}\text { The priorities for } \\
\text { implementation of curriculum } \\
\text { are chosen on the basis of } \\
\text { feedback. }\end{array}$ & $\begin{array}{l}\mathrm{N} \\
\%\end{array}$ & $\begin{array}{l}4 \\
17.4\end{array}$ & $\begin{array}{l}9 \\
39.1\end{array}$ & $\begin{array}{l}9 \\
39.1\end{array}$ & $\begin{array}{l}1 \\
4.4\end{array}$ & 2.30 \\
\hline 12 & $\begin{array}{l}\text { There is a continuous } \\
\text { monitoring of curriculum at } \\
\text { secondary level. }\end{array}$ & $\begin{array}{l}\mathrm{N} \\
\%\end{array}$ & $\begin{array}{l}1 \\
4.4\end{array}$ & $\begin{array}{l}14 \\
60.9\end{array}$ & $\begin{array}{l}8 \\
34.8\end{array}$ & $\begin{array}{l}0 \\
-\end{array}$ & 2.30 \\
\hline 13 & $\begin{array}{l}\text { Supervisory staff } \begin{array}{l}\text { regularly } \\
\text { monitors the } \\
\text { curriculum } \\
\text { implementation. }\end{array} \\
\end{array}$ & $\begin{array}{l}\mathrm{N} \\
\%\end{array}$ & $\begin{array}{l}2 \\
8.7\end{array}$ & $\begin{array}{l}13 \\
56.5\end{array}$ & $\begin{array}{l}8 \\
34.8\end{array}$ & $\begin{array}{l}0 \\
-\end{array}$ & 2.26 \\
\hline 14 & $\begin{array}{l}\text { Ministry of education seeks feed } \\
\text { back from monitoring staff. }\end{array}$ & $\begin{array}{l}\mathrm{N} \\
\%\end{array}$ & $\begin{array}{l}1 \\
4.4\end{array}$ & $\begin{array}{l}11 \\
47.8\end{array}$ & $\begin{array}{l}10 \\
43.5\end{array}$ & $\begin{array}{l}1 \\
4.4\end{array}$ & 2.48 \\
\hline 15 & $\begin{array}{l}\text { Teachers' responses are valuable } \\
\text { for the monitoring of } \\
\text { curriculum. }\end{array}$ & $\begin{array}{l}\mathrm{N} \\
\%\end{array}$ & $\begin{array}{l}1 \\
4.4\end{array}$ & $\begin{array}{l}10 \\
43.5\end{array}$ & $\begin{array}{l}9 \\
39.1\end{array}$ & $\begin{array}{l}3 \\
13.0\end{array}$ & 2.61 \\
\hline 16 & $\begin{array}{l}\text { Data obtained from monitoring } \\
\text { is used for improving existing } \\
\text { curriculum. }\end{array}$ & $\begin{array}{l}\mathrm{N} \\
\%\end{array}$ & $\begin{array}{l}1 \\
4.4\end{array}$ & $\begin{array}{l}12 \\
52.2\end{array}$ & $\begin{array}{l}9 \\
39.1\end{array}$ & $\begin{array}{l}1 \\
4.4\end{array}$ & 2.43 \\
\hline 17 & $\begin{array}{l}\text { Monitoring is carried out at } \\
\text { curriculum development level. }\end{array}$ & $\begin{array}{l}\mathrm{N} \\
\%\end{array}$ & $\begin{array}{l}1 \\
4.4\end{array}$ & $\begin{array}{l}8 \\
34.8 \\
\end{array}$ & $\begin{array}{l}13 \\
56.5\end{array}$ & $\begin{array}{l}1 \\
4.4\end{array}$ & 2.61 \\
\hline 18 & $\begin{array}{l}\text { Monitoring is carried out at } \\
\text { school management level. }\end{array}$ & $\begin{array}{l}\mathrm{N} \\
\%\end{array}$ & $\begin{array}{l}2 \\
8.7\end{array}$ & $\begin{array}{l}7 \\
30.4\end{array}$ & $\begin{array}{l}13 \\
56.5\end{array}$ & $\begin{array}{l}1 \\
4.4\end{array}$ & 2.57 \\
\hline 19 & $\begin{array}{l}\text { Monitoring is carried out at } \\
\text { class teaching level. }\end{array}$ & $\begin{array}{l}\mathrm{N} \\
\%\end{array}$ & $\begin{array}{l}2 \\
8.7\end{array}$ & $\begin{array}{l}10 \\
43.5\end{array}$ & $\begin{array}{l}10 \\
43.5\end{array}$ & $\begin{array}{l}1 \\
4.4\end{array}$ & 2.43 \\
\hline 20 & $\begin{array}{l}\text { Monitoring is carried out at } \\
\text { student achievement level. }\end{array}$ & $\begin{array}{l}\mathrm{N} \\
\%\end{array}$ & $\begin{array}{l}4 \\
17.4\end{array}$ & $\begin{array}{l}9 \\
39.1\end{array}$ & $\begin{array}{l}9 \\
39.1\end{array}$ & $\begin{array}{l}1 \\
4.4\end{array}$ & 2.30 \\
\hline
\end{tabular}

Table shows that majority of curriculum experts $(82 \%$, mean score $=2.87)$ agreed that there is proper mechanism for implementation of curriculum at secondary level. Majority $(74 \%$, mean score $=2.70)$ of respondents agreed that curriculum provides adequate guidelines for its implementation. (39\%, mean score $=2.48)$ curriculum experts disagreed that instructions are made available for curriculum implementation to school heads. Majority of curriculum experts $(78 \%$, mean score $=2.74)$ agreed that guidelines clarify the pattern of teacher-learner interaction in science class. Majority $(78 \%$, mean score $=2.09)$ of respondents disagreed that teachers' training is ensured before implementation of new curriculum. Majority of curriculum experts $(56 \%$, mean score $=2.39)$ disagreed that resource material is provided for implementation of new curriculum. Majority $(74 \%$, mean score $=2.74)$ of respondents agreed that curriculum action plans include target for student achievement. Majority of curriculum experts $(48 \%$, mean score $=2.48)$ disagreed that impact of implementation of curriculum is determined by classroom practice. Majority $(74 \%$, mean score $=2.87)$ of respondents agreed that impact of implementation of curriculum is determined by pupil achievement. Majority of curriculum experts $(61 \%$, mean score $=2.57)$ agreed that self-evaluation process is embedded in the curriculum implementation process. Majority $(56 \%$, mean score $=2.30$ ) of respondents disagreed that priorities for implementation of curriculum are chosen on the basis of feedback. Majority of curriculum experts $(65 \%$, mean score $=2.30)$ disagreed that there is a continuous monitoring of curriculum at secondary level. Majority $(65 \%$, mean score $=2.26)$ of respondents disagreed that supervisory staff regularly monitors the curriculum implementation. Majority of curriculum experts $(52 \%$, mean score $=2.48)$ disagreed that ministry of education seeks feed back from monitoring staff. Majority (52\%, mean score $=2.61$ ) of respondents agreed that teachers' responses are valuable for the 
monitoring of curriculum. Majority of curriculum experts $(57 \%$, mean score $=2.43)$ disagreed that data obtained from monitoring is used for improving existing curriculum. Majority $61 \%$, mean score $=2.61$ ) of respondents agreed that monitoring is carried out at curriculum development level. Majority of curriculum experts $(61 \%$, mean score $=2.57)$ agreed that monitoring is carried out at school management level. Majority $(52 \%$, mean score $=2.43)$ of respondents disagreed that monitoring is carried out at class teaching level. Majority of curriculum experts $(56 \%$, mean score $=2.30)$ disagreed that Monitoring is carried out at student achievement level.

\section{Major Findings}

Majority of curriculum experts agreed that there is proper mechanism for implementation of curriculum at secondary level, curriculum provides adequate guidelines for its implementation, guidelines clarify the pattern of teacher-learner interaction in science class but instructions were not made available for curriculum implementation to school heads and that the teachers' training was not ensured before implementation of new curriculum. According to majority of curriculum experts, resource material was not provided for implementation of new curriculum. Majority of curriculum experts agreed that curriculum action plans include target for student achievement but the impact of implementation of curriculum was not determined by classroom practice. Majority of respondents agreed that impact of implementation of curriculum is determined by pupil achievement and self-evaluation process is embedded in the curriculum implementation process but the priorities for implementation of curriculum were not chosen on the basis of feedback. According to most of curriculum experts instructions were not made available for curriculum implementation to school heads and there was no mechanism for continuous monitoring of curriculum at secondary level and that ministry of education rarely seeks feed back from monitoring staff. Majority of respondents agreed that teachers' responses are valuable for the monitoring of curriculum but this type of feedback was never used for improving existing curriculum because no such monitoring was carried out at any level in past.

\section{Conclusions}

Adequate guidelines and teacher training is not ensured before launching new curriculum consequently teachers are not able to refine the national curriculum according to their particular needs and needs of their students. Monitoring system to identify weaknesses of existing curriculum, textual material, teachers' delivery and policy formulation does not functionally exist at SSC level in Punjab. Consequently feedback for proper evaluation and improvement of existing curricula is not available. Moreover process of continuous curriculum improvement and continuous curriculum revision is not in practice. Curriculum reform in science education at SSC level does not benefit the school system due to huge gap that takes apart curriculum objectives and their implementation through scheme of study, course contents, science teaching and assessment procedures. The study revealed that in Punjab experts tend to emphasize more on one aspect of curriculum i.e. preparing a curriculum document and ignore the other aspect i.e. they ignore the important aspects like proper teacher education programmes; suitable curriculum monitoring mechanism; appropriate process of curriculum evaluation and exact teachers' role in curriculum development process.

\section{Recommendations}

Feedback is generally the outcome of a systematic monitoring that has been now considered the key to successful implementation of the curriculum. It seems necessary to identify weaknesses of existing curriculum and textual material through a continuous monitoring and evaluation mechanism. A checklist should be prepared with newly designed curriculum document for the monitoring and evaluation of curriculum. The check list should incorporate 


\section{Macrothink $\Delta$ Institute ${ }^{m}$}

different aspects and phases of curriculum development and implementation. The feedback should be used for improvement of existing curriculum.

\section{References}

Ajibola, M. A. (2008). Innovations and Curriculum Development for Basic Education in Nigeria: Policy Priorities and Challenges of Practice and Implementation. Research Journal of International Studies. Issue 8, p. 51-58

Balim, A. G. and Kucuk, H. (2010). Examining of Turkish and Portuguese Education Systems and Science Curricula. Procedia Social and Behavioral Sciences. (9), 26-32

Farooq. R. A. (1985). Curriculum Development in Pakistan. AEPM, Islamabad.

Government of Pakistan (2006). Green Paper on National Education Policy Review Process: Textbook and Learning Materials. Islamabad: Policy and Planning Wing, Ministry of Education.

Government of Pakistan (2009). National Education Policy. Islamabad: Ministry of education. Iqbal, M. (2011). Education in Pakistan: Developmental Milestones. Karachi: Paramount Publishing Enterprise.

Ornstein, A. C. and Hunkins, F. P. (1993). Curriculum Foundations, Principles and Issues. USA: Allyn and Bacon.

Ravi, S.K. (2000). Teaching of Sciences. New Delhi: Mangal Deep Publications.

Shami, P. A. (1993). Elementary Science Programme. Institute for the Promotion of Science Education and Training. Islamabad: Ministry of Education Pakistan.

Usta, D. U., Ceng, Z, Kasli, F. and Ayas, A. (2009). Evaluation of Implementation of Compounds Unit at $9^{\text {th }}$ Grade in the New Chemistry Curriculum. Procedia Social and Behavioral Sciences. (1), 2359-2362 